\section{Phytotoxicity of Selected Insecticides on Greenhouse-grown Herbs}

\author{
Raymond A. Cloyd \\ University of Illinois, Department of Natural Resources and Environmental \\ Sciences, 384 National Soybean Research Laboratory, 1101 West Peabody \\ Drive, Urbana, IL 61801
}

Nina L. Cycholl

H.M. Buckley and Sons Inc., P.O. Box 1237, Springfield, IL 62705

Additional index words. Spanish lavender, oregano, rosemary, St. Johnswort, wolly thyme, nutmeg thyme, Beauveria bassiana, pyrethrin, azadirachtin, potassium salts of fatty acids, cinnamaldehyde, paraffinic oil, capsaicin

\begin{abstract}
A greenhouse study was conducted from Oct. 1999 through Feb. 2000, and Mar. 2001 through Apr. 2001, to determine the potential phytotoxic effects of selected insecticides on Spanish lavender (Lavandula stoechas L.), oregano (Origanum vulgare L. 'Santa Cruz'), rosemary (Rosmarinus officinalis L.), St. Johnswort (Hypericum perforatum L. 'Topaz'), wolly thyme (Thymus vulgaris L. 'Wolly'), and nutmeg thyme (Thymus vulgaris L. 'Nutmeg'). Insecticides used for the study were Beauveria bassiana Strain GHA, pyrethrin [+ piperonyl butoxide (PBO)], azadirachtin, potassium salts of fatty acids, two rates of cinnamaldehyde, paraffinic oil, and capsaicin. Visual observations of phytotoxicity were made 7 days after the final application. Pyrethrin, potassium salts of fatty acids, and both rates of cinnamaldehyde were consistently more phytotoxic than the other insecticides. Despite the phytotoxic effects from some of the insecticides, new growth that emerged following treatments compensated for the initial damage, and the herbs were still saleable.
\end{abstract}

Herbs are used throughout the United States for culinary and medicinal purposes. Total sales of culinary herbs were $\$ 30.9$ million in 1998 (USDA, 1998). The annual retail sales of medicinal herb use in the United States in 1994 was $\$ 1.6$ billion and nearly $\$ 4.0$ billion in 1998 (Brevoort, 1998). Popular herbs grown in greenhouses include basil (Ocimum basilicum L.), chives (Allium schoenoprasum L.), dill (Anethum graveolens L.), lavender (Lavandula angustifolia Mill.), mint (Mentha sp. L.), parsley (Petroselinum crispum Mill.), rosemary (Rosmarinus officinalis L.), sage (Salvia officinalis L.), scented geraniums (Pelargonium sp. Jacq.), and thyme (Thymus vulgaris L.) (Cox and Craker, 1994a). Similar to other greenhouse-grown crops, herbs are susceptible to a diversity of insect and mite pests, including aphids, whiteflies, fungus gnats, and spider mites (Gibson et al., 2000). The number of pest control materials registered for herbs, however, is limited because of liability and the fact that herbs are considered a minor or specialty crop (Cox and Craker, 1994b).

Pest control materials registered for use on herbs are generally considered reduced-risk insecticides because these pesticides are less toxic to workers, have short residual properties, and have minimal environmental impact (Lowery and Isman, 1995; Parrella et al., 1983). These materials also have a narrow spectrum of pest activity and generally take longer to kill pests. Although some insecticides are registered for use on herbs, these materials may not have been tested on all herb species or on

Received for publication 18 June 2001. Accepted for publication $28 \mathrm{Jan} .2002$. plants at different maturities. Currently, only a minimal amount of information is available on the phytotoxicity of these insecticides to herbs.

Greenhouse managers need information on which insecticides are safe to apply on herbs because any phytotoxic effects may limit the use of these registered materials, thus making it difficult to manage insect and mite pests. Furthermore, these materials cannot leave unsightly residues or cause tissue discoloration, which would reduce the market value of herbs (Ahmed et al., 2001). The objective of this study was to evaluate various reducedrisk insecticides for phytotoxicity on a select group of commonly grown herb species at two different growth stages.

\section{Materials and Methods}

A greenhouse insecticide study, divided into two experiments and replicated over two growing seasons, was conducted at H.M. Buckley and Sons, Inc., Springfield, Ill. The first experiment was conducted from Oct. 1999 through Feb. 2000. The second experiment was conducted from Mar. 2001 through Apr. 2001. Within each experiment there were two treatment groups with four treatments and a control (untreated check) per group for all herb species. In experiment one, both groups were done consecutively because of space restrictions at the greenhouse facility. As a result, the first experiment was conducted over a longer time period (5 months). In experiment two, both treatment groups were conducted simultaneously. Herbs used for study were 5- and 9-week-old plants of Spanish lavender (Lavandula stoechas L.), oregano
(Origanum vulgare L. 'Santa Cruz'), rosemary (Rosmarinus officinalis L.), St. Johnswort (Hypericum perforatum L. 'Topaz'), wolly thyme (Thymus vulgaris L. 'Wolly'), and nutmeg thyme (Thymus vulgaris L. 'Nutmeg'). These herbs were selected for the study because they are widely grown by the greenhouse operation and they are the more popular types among the customer base.

For each experiment, the 5- and 9-weekold plants were started from cuttings taken from stock plants. After rooting, cuttings were potted into 10.16-cm plastic containers (TLC Polyform Inc., Plymouth, Minn.). The growing medium used for the study consisted of $30 \% 0.635-\mathrm{cm}$ bark, $30 \%$ peat, $20 \%$ medium vermiculite, and $20 \%$ perlite. Plants were fertilized using a constant liquid feed program with $20 \mathrm{~N}-8.3 \mathrm{P}-8.8 \mathrm{~K}$ at $200 \mathrm{mg} \cdot \mathrm{L}^{-1}$. Plants were placed in a glass greenhouse $(16.0 \times 5.3$ $\mathrm{m})$ on four raised benches $(3.7 \times 1.5 \mathrm{~m})$ in a completely randomized design. There were five treatments each with five replications for each herb species and age class for a total of 600 plants (100 plants for each species). Plants were grown under natural daylight conditions with temperatures between 20 and $28^{\circ} \mathrm{C}$.

The insecticide treatments and rates for the first group were Beauveria bassiana Strain GHA (Botanigard, Mycotech Corp., Butte, Mont.) at $2.50 \mathrm{~mL} \cdot \mathrm{L}^{-1}$, pyrethrin [+ piperonyl butoxide (PBO)] (Pyrenone; AgrEvo Environmental Health Inc., Montvale, N.J.) at 1.94 $\mathrm{mL} \cdot \mathrm{L}^{-1}$, azadirachtin (Azatin; Olympic Horticultural Products, Bradenton, Fla.) at 1.25 $\mathrm{mL} \cdot \mathrm{L}^{-1}$, or potassium salts of fatty acids (Insecticidal soap; Olympic Horticultural Products) at $19.4 \mathrm{~mL} \cdot \mathrm{L}^{-1}$. The insecticide treatments and rates for the second group were cinnamaldehyde (Cinnamite; Mycotech Corp.) at $6.61 \mathrm{~mL} \cdot \mathrm{L}^{-1}$ or $4.98 \mathrm{~mL} \cdot \mathrm{L}^{-1}$, paraffinic oil (Ultrafine Oil; Whitmire Micro-Gen Research Laboratories, Inc., St. Louis) at $9.96 \mathrm{~mL} \cdot \mathrm{L}^{-1}$, or capsaicin (Hot Pepper Wax; Hot Pepper Wax, Greenville, Pa.) at $62.25 \mathrm{~mL} \cdot \mathrm{L}^{-1}$. Both groups had a control of no treatment. The insecticides used in this study were selected because they are registered for herbs in greenhouse production systems. The rates used were based on manufacturer label recommendations for herbs. All insecticides were sprayed to run-off with a 9.5-L capacity hand pump sprayer (model 030; PEX Greenlawn, Somerset, $\mathrm{Pa}$.).

Three applications of each treatment were made at 7-d intervals, with temperatures during the applications ranging from 18 to $28^{\circ} \mathrm{C}$ for the first experiment and 23 to $25^{\circ} \mathrm{C}$ for the second experiment. The outdoor weather conditions during insecticide applications were generally overcast (scattered clouds). Plants were watered regularly in order to minimize plant stress, as environmental conditions, such as low air speed or high relative humidity, and cultural stresses may predispose plants to phytotoxicity (Davidson et al., 1991; Taiz and Zieger, 1991). In addition, all spray applications were performed in the morning so that any phytotoxic effects were due directly to the insecticides. A numerical phytotoxicity rating scale from 0 to $3[0=$ no visible injury; $1=$ light 
injury, $25 \%$ foliar injury, no influence on marketability; $2=$ moderate injury, $50 \%$ foliar injury, reduced market quality; and $3=$ complete foliar injury, $>75 \%$ foliar injury, not marketable] was used to describe the extent of phytotoxicity from the insecticide treatments. This numerical rating scale is similar to the one used by Poe (1970) for evaluating phytotoxicity on chrysanthemums. Typical plant injury on herbs expressing phytotoxic symptoms was a marginal leaf burn (necrosis). Visual evaluations were conducted $7 \mathrm{~d}$ after the final insecticide treatment. Plants were individually evaluated for phytotoxicity.

Data from both experiments within the two treatment groups were independently analyzed using a completely randomized design 2-way analysis of variance (SAS Institute, 1996) to determine the mean phytotoxicity rating for each treatment. Lack of significant age class effect allowed us to pool the two different age classes before analysis. Significant means were separated using a Fisher's protected least significant difference (LSD) mean separation test.

\section{Results and Discussion}

In experiment one, pyrethrin [+ piperonyl butoxide (PBO)], potassium salts of fatty acids, and both rates of cinnamaldehyde were significantly more phytotoxic than the other treatments and the control (Table 1). The high rate of cinnamaldehyde $\left(6.61 \mathrm{~mL} \cdot \mathrm{L}^{-1}\right)$ had a significantly higher phytotoxicity rating than the lower rate $\left(4.98 \mathrm{~mL} \cdot \mathrm{L}^{-1}\right)$. Beauveria bassiana, azadirachtin, capsaicin, and paraffinic oil were not phytotoxic to any of the herb species tested (Table 1).

Results from experiment two were similar to experiment one with the same four treatments causing significantly more phytotoxicity than the other treatments and the control (Table 2). Although plants treated with capsaicin and paraffinic oil exhibited minor phytotoxic symptoms, they were not significantly different from the control (Table 2).

Despite the phytotoxic effects from some of the insecticides, new growth that emerged following treatments appeared to overcome the initial injury. As a result, plants at the conclusion of the study were still saleable as determined subjectively by the herb production manager. This type of response has occurred with other pesticides such as acaricides/ miticides where reductions in stomatal openings caused by the phytotoxic effects were temporary (Lapre et al., 1982). No significant effect could be attributed to the age of the plants when they were treated.

A possible reason why the insecticides tested did not harm most of the herb types is because the plants possess a waxy or thick leaf cuticle, which may have protected them (Taiz and Zeiger, 1991). This may be due to the physiological nature of the leaf surface. Of all the herb types, St. Johnswort demonstrated the highest sensitivity to the insecticides, especially to both rates of cinnamaldehyde. This may be because St. Johnswort has a thinner leaf cuticle compared to the other herb types.

Initial research with cinnamaldehyde has

Table 1. Mean phytotoxicity rating for all insecticide treatments in experiment one (group one and two) with five replications per treatment per each herb species $(n=6)$ and age class $(5$ - and 9-week-old plants). Greenhouse temperatures were between 18 and $28{ }^{\circ} \mathrm{C}$ and plants were grown under natural daylight conditions.

\begin{tabular}{|c|c|c|c|c|c|}
\hline $\begin{array}{l}\text { Group one } \\
\text { treatment }\end{array}$ & $\begin{array}{l}\text { Product } \\
\text { label rate } \\
\left(\mathrm{mL} \cdot \mathrm{L}^{-1}\right)\end{array}$ & $\begin{array}{c}\text { Mean } \\
\text { phytotoxicity } \\
\text { rating }\end{array}$ & $\begin{array}{c}\text { Group two } \\
\text { treatment }\end{array}$ & $\begin{array}{l}\text { Product } \\
\text { label rate } \\
\left(\mathrm{mL} \cdot \mathrm{L}^{-1}\right)\end{array}$ & $\begin{array}{c}\text { Mean } \\
\text { phytotoxicity } \\
\text { rating }\end{array}$ \\
\hline Pyrethrin (+ PBO) & 1.94 & $0.22 \mathrm{a}^{2}$ & Cinnamaldehyde & 6.61 & $0.67 \mathrm{a}^{2}$ \\
\hline Potassium salts of fatty acids & 19.40 & $0.11 \mathrm{~b}$ & Cinnamaldehyde & 4.98 & $0.22 \mathrm{~b}$ \\
\hline Beauveria bassiana & 2.50 & $0.00 \mathrm{c}$ & Capsaicin & 62.25 & $0.00 \mathrm{c}$ \\
\hline Azadirachtin & 1.25 & $0.00 \mathrm{c}$ & Paraffinic oil & 9.96 & $0.00 \mathrm{c}$ \\
\hline Control & --- & $0.00 \mathrm{c}$ & Control & --- & $0.05 \mathrm{c}$ \\
\hline
\end{tabular}

${ }^{2}$ Means not followed by a common letter are significantly different $(P=0.05)$ as determined by Fisher's protected least significant difference (LSD) test.

Table 2. Mean phytotoxicity rating for all insecticide treatments in experiment two (group one and two) with five replications per treatment per each herb species $(n=6)$ and age class (5- and 9-week-old plants). Greenhouse temperatures were between 18 to $28{ }^{\circ} \mathrm{C}$ and plants were grown under natural daylight conditions.

\begin{tabular}{lccccc}
\hline \hline $\begin{array}{l}\text { Group one } \\
\text { treatment }\end{array}$ & $\begin{array}{c}\text { Product } \\
\text { label rate } \\
\left(\mathrm{mL} \cdot \mathrm{L}^{-1}\right)\end{array}$ & $\begin{array}{c}\text { Mean } \\
\text { phytotoxicity } \\
\text { rating }\end{array}$ & $\begin{array}{c}\text { Group two } \\
\text { treatment }\end{array}$ & $\begin{array}{r}\text { Product } \\
\text { label rate } \\
\left(\mathrm{mL} \cdot \mathrm{L}^{-1}\right)\end{array}$ & $\begin{array}{c}\text { Mean } \\
\text { phytotoxicity } \\
\text { rating }\end{array}$ \\
\hline Pyrethrin (+ PBO) & 1.94 & $0.22 \mathrm{a}^{\mathrm{z}}$ & Cinnamaldehyde & 6.61 & $0.33 \mathrm{a}^{\mathrm{z}}$ \\
Potassium salts of fatty acids & 19.40 & $0.22 \mathrm{a}$ & Cinnamaldehyde & 4.98 & $0.33 \mathrm{a}$ \\
Beauveria bassiana & 2.50 & $0.00 \mathrm{~b}$ & Capsaicin & 62.25 & $0.11 \mathrm{~b}$ \\
Azadirachtin & 1.25 & $0.00 \mathrm{~b}$ & Paraffinic oil & 9.96 & $0.11 \mathrm{~b}$ \\
Control & --- & $0.00 \mathrm{~b}$ & Control & -- & $0.00 \mathrm{~b}$ \\
\hline
\end{tabular}

${ }^{2}$ Means not followed by a common letter are significantly different $(P=0.05)$ as determined by Fisher's protected least significant difference (LSD) test.

shown that it was phytotoxic to poinsettia (Euphorbia pulcherrima Willd. Ex Klotzsch) (Parrella et al., 1999). However, it was noted that this might be due to a formulation problem and not a direct affect of the active ingredient. In those studies, no phytotoxicity was demonstrated on rosemary and thyme at $0.25 \%$ cinnamaldehyde; however, $0.50 \%$ cinnamaldehyde was phytotoxic to thyme (Parrella et al., 1999).

Although oils generally have a higher probability of causing phytotoxicity (Davidson et al., 1991), this was not the case in this study. For example, paraffinic oil (UltraFine oil), which was one of the treatments in this study, has demonstrated safety to flowers and fruit (Lawson and Weires, 1991).

This study demonstrated that several registered insecticides were phytotoxic to certain herbs. However, the overall effects were not significant enough to reduce market quality and salability. Furthermore, most insecticides tested showed no chronic phytotoxic effects. These insecticides are useful for controlling pests on herbs because they have short residual activity, which minimizes any potential effects from spray residues. The number of pest control materials registered for herbs is limited as herbs are considered a specialty or minor crop and there is the issue of liability since they may be consumed during cooking. The information produced from this study will help greenhouse managers when selecting pest control materials to manage insects and mites on herbs.

\section{Literature Cited}

Ahmed, M.T., N. Loutfy, and Y. Yousef. 2001. Contamination of medicinal herbs with organophosphorus insecticides. Bul. Environ. Contam. Toxicol. 66(4):421-426.

Brevoort, P. 1998. The booming U.S. botanical market: A new overview. Herbalgram 44:33-45.
Cox, D. and L. Craker. 1994a. Herbs: If you grow them they will sell. Greenhouse Mgr. 12:59-62.

Cox, D. and L. Craker. 1994b. Herbs: Grow them and they will sell. Greenhouse Manager 12:74-77.

Davidson, N.A., J.E. Dibble, M.L. Flint, P.L. Marer, and A. Guye. 1991. Managing insects and mites with spray oils. Univ. Calif. Div. Agr. Natur. Res. Pub. 3347.

Gibson, J.L., B.E. Whipker, and R. Cloyd. 2000. Success with container production of twelve herb species. North Carolina Flower Growers' Bul. 45:1-9.

Lapre, L.F., F.V. Sances, N.C. Toscano, E.R Oatman, V. Voth, and M.W. Johnson. 1983. The effects of acaricides on the physiology, growth, and yield of strawberries. J. Econ. Entomol. 75(4):616-619.

Lawson, D.S. and R.W. Wieres. 1991. Management of European red mite (Acari: Tetranychidae) and several aphid species on apple with petroleum oils and an insecticidal soap. J. Econ. Entomol. 84(5):1550-1557.

Lowery, D.T. and M.B. Isman. 1995. Toxicity of neem to natural enemies of aphids. Phytoparasitica 23:297-306.

Parrella, M.P., D. von Damm-Kattari, G. von DammKattari, and B. Murphy. 1999. Cinnamite: The ideal reduced-risk pesticide. Grower Talks 63:82-90.

Parrella, M.P., G.D. Christie, and K.L. Robb. 1983. Compatibility of insect growth regulators and Chrysocharisparksi (Hymenoptera:Eulophidae) for the control of Liriomyza trifolii (Diptera: Agromyzidae). J. Econ. Entomol. 76:949-951.

Poe, S.L. 1970. Evaluations of pesticides for phytotoxicity on chrysanthemum flowers. Proc. Fla. State Hort. Sci. 83:469-471.

SAS Institute. 1996. SAS system for Windows, version 6:12. SAS Inst., Cary, N.C.

Taiz, L. and E. Zieger. 1991. Chapter 13: Surface protection and secondary defense compounds, p. 318-345. In: Plant Physiology. Benjamin/ Cummings Publ. Co. Inc., Redwood City, Calif.

USDA. 1998. Census of horticultural specialties. Nat. Agr. Stat. Serv., Washington, D.C. (http:// www.usda.gov/nass) 